\title{
SPECIFIC GENES AFFECTING BODY WEIGHT IN IRAQI AWASSI SHEEP
}

\author{
Yousif M. S. Al-BARZInJi ${ }^{*}$ and Aso A. AMEen ${ }^{* *}$ \\ *Dept. of Animal Resources, College of Agricultural Engineering Sciences, University of Salahaddin, \\ Kurdistan Region-Iraq \\ ** Ministry of Agriculture \& Water Resources-Kurdistan Region- Iraq
}

(Accepted for Publication: October 21, 2019)

\begin{abstract}
The present study was to investigate genotypes of three genes (MSTN, CAST and MHC-DRB1) that related to body weight in Awassi lambs. A total of 52 lambs were used. The DNA concentration and DNA purity (A260/280) was calculated automatically by nanodrop and ranged between $10.53-53.94 \mathrm{ng} / \mu \mathrm{l}$ and 1.51-2.19, respectively. The RFLP-PCR results showed that the CAST and MHC-DRB1genes were polymorphism among individuals while the MSTN gene was monomorphism. Lambs with CC genotype for MHC-DRB1 locus have positive effect on body weight at most ages while lambs with AB genotype for CAST locus gave higher body weight at all ages and higher average daily gain. The lambs with BBCCBB genotypes for the three genes under study gave higher weight at weaning $(22.15 \mathrm{~kg} / \mathrm{lamb})$ and higher average daily gain $(0.197 \mathrm{~kg} / \mathrm{lamb} / \mathrm{day})$ compared with all other genotypes. These results showed that Awassi lambs have potential for growth traits and the selection process with the aid of molecular technique can play a positive and rapid role for improvement this breed of sheep.
\end{abstract}

KEYWORDS: RFLP-PCR, MSTN, CAST, MHC-DRB1, Weaning weight.

https://doi.org/10.26682/cajuod.2020.22.2.21

\section{INTRODUCTION}

$\mathbf{T}$ The native sheep breeds in Iraq are fattailed and carpet-wool type and are raised mainly for lamb and mutton production (Al-Rawi et al., 1996; Al-Azzawi et al., 1995; Al-Barzinji and Gardi, 2012 and 2015). The Awassi sheep, the most numerous small ruminant breed of Iraq $(58.2 \%)$, are predominantly white with brown or red faces (FAO, 2000). Selection of farm animals depends on the availability of information's in animals. Classic breeding methodology by estimating breeding values requires a lot of efforts, time and fund. Identifying major genes can speed up (at more precise and accurate) genetic improvement of economic traits of sheep breeds. Identification and characterization of breeds is required to identify the genetic resources and also to prioritize breeds for conservation and development. Recently, the use of molecular markers, revealing polymorphism at the DNA level, has been playing an increasing role in animal genetics studies (Baumung et al., 2004).

Improvement of livestock has focused on the selection of breeding individuals with superior phenotypes. With the development of increasingly advanced statistical methods that maximize selection for genetic gain, this simple approach has been extremely successful in increasing the quantity of agricultural output and productivity. However, information now available on the organization and functioning of the genome could be used in breeding programmers to improve a range of traits. Strategies to identify markers for traits and the application of these markers are described by reference to examples of loci that control a range of different traits (Williams, 2005).

Therefore, the objective of the present study is to identify the genetic polymorphism and best genotypes for lamb's growth using PCR-RFLP for three specific genes MSTN, CAST and MHC-DRB1.

\section{MATERIALS AND METHODS}

\section{Experimental Animals and Locations}

This study was undertaken in commercial flock of Awassi sheep at the Bashblakh village / Kirkuk governorate (30 km east of Kirkuk). Ewes are exposed to rams for mating during end of May to the end of October, so that ewes

\footnotetext{
*E-Mail: Yousif.Noori@Su.Edu.Krd, Y Y_Barzengy@Yahoo.com
} 
lambing occurred by end of October to end of November. A total of 52 ewes lambed out of 58 ewes mated, giving 52 lambs, six of them died during experiment. At lambing ewes and lambs were identified. Sexes, month of lambing were recorded. Ewes and lambs were raised together until weaning at 90 days of age. Male and female lambs were weighed at birth, one, two and three months of age.

\section{Blood Collection and DNA Extraction}

Whole blood was collected from each lamb at the end of the experiment through jugular vein into $5 \mathrm{ml}$ Vacutainer tubes containing the anticoagulant, ethylenediaminetetra-acetic acid (EDTA). Samples were stored at $-20^{\circ} \mathrm{C}$ until DNA extraction. All research works were carried out in both laboratory of Animal Molecular
Genetics/College of Agriculture and Molecular Biology/Scientific Research Center/ Salahaddin University. Genomic DNA was isolated from samples using extraction kit (GeNet Bio, koria). The quantity and quality of DNA was checked by Nanodrop spectrophotometer and gel electrophoresis.

\section{PCR Primers}

The PCR programs were occurred out according to RFLP strategy portrayed by Davis et al., (2000), Hanrahan et al., (2004), Chu et al., (2007) and Moradband et al., (2011). Primers name, sequencing of primers with their restriction fragments are recorded in tables (1 and

2).

Table (1): Primers, Restriction Enzymes and restriction site for Candidate genes.

\begin{tabular}{|c|c|c|c|c|c|}
\hline \multirow{2}{*}{$\begin{array}{l}\text { Gene } \\
\text { symbol }\end{array}$} & \multicolumn{2}{|c|}{ Primer sequences } & \multirow[t]{2}{*}{$\mathrm{RE}$} & \multirow[t]{2}{*}{ Restriction site } & \multirow[t]{2}{*}{ Reference } \\
\hline & Forward & Reverse & & & \\
\hline \multirow{4}{*}{ CAST } & & & \multirow{4}{*}{ Mspl } & 5' ---C CGG--- 3' & \multirow{4}{*}{$\begin{array}{l}\text { Shahroudi et } \\
\text { al., (2011) }\end{array}$} \\
\hline & 5'-TGGGGC & 5'- GGTGGAG & & 3' ---GGC C--- 5' & \\
\hline & CCAATGACGCCATG & C AGCACTTC & & & \\
\hline & ATG- $3^{\prime}$ & TGATCACC-3' & & & \\
\hline \multirow{4}{*}{ MSTN } & & & \multirow{4}{*}{ Dral } & 5' ---TTT AAA--- 3' & \multirow{4}{*}{$\begin{array}{l}\text { Shahram and } \\
\text { Majid (2014) }\end{array}$} \\
\hline & 5'-TGGCGTTA & 5'-AACAGCA & & $3^{\prime}$---AAA TTT--- 5' & \\
\hline & CTCAAAA & GTCAGCAG & & & \\
\hline & GCAAA $-3^{\prime}$ & AGTCG-3' & & & \\
\hline \multirow{4}{*}{ MHCDRB1 } & & & \multirow{4}{*}{ Rsal } & 5' ---GT AC--- 3' & \multirow{4}{*}{$\begin{array}{c}\text { Ammer et al., } \\
\text { (1992) }\end{array}$} \\
\hline & 5'-TCTCTGCA & 5'-CTCGCCG & & $3^{\prime}$---CA TG--- 5' & \\
\hline & GCACATTT & CTGCACAG TGAAAC-3' & & & \\
\hline & CCTGG-3 & & & & \\
\hline
\end{tabular}

\section{PCR Amplification}

Thermo cycler (Applied Biosystems ${ }^{\circledR}$ Veriti ${ }^{\circledR}$ 96-Well Thermal Cycler Singapore) was conveyed in a final reaction volume of $20 \mu 1$. A master mix for (46) samples for every gene was readied and an aliquot of $15 \mu$ filled in every PCR tube. Five $\mu$ of DNA sample was added to each tube to make the last volume $20 \mu 1$ [(A GoTaq blue Master Mix $10 \mu 1,25$ units/ml Taq polemerase,each dNTPs is $200 \mathrm{mM}$ and $\mathrm{MgCl} 2$ is $1.5 \mathrm{mM}$ ), $2 \mu \mathrm{L}$ RFLP primer (forward and reveres), $5 \mu 1$ (50ng) of DNA template and $3 \mu 1$ DNase free water)], (so as to accomplish homogeneity of reagents and decrease the risk of contamination, control reaction were situated up without genomic DNA). DNA was amplified initial denaturation at $95^{\circ} \mathrm{C}$ for $5 \mathrm{~min}$, followed by 30 cycles consisting of denaturation at $95^{\circ} \mathrm{C}$ for $30 \mathrm{sec}$, annealing $60^{\circ} \mathrm{C}$ for $1 \mathrm{~min}$, extension at $72^{\circ} \mathrm{C}$ for $1 \mathrm{~min}$, with final extension $72^{\circ} \mathrm{C}$ for $7 \mathrm{~min}$. The amplification products were sizefractionated in a $2 \%$ agarose gel containing Ethidium Bromide in Tris-borate EDTA buffer and visualized under UV transillumination.

\section{PCR -RFLP Analaysis}

Following PCR amplification the digested PCR products with the appropriate restriction enzyme for each PCR products separately was carried out to identify if a mutation is present in a DNA samples or not. All digestion component 
requirements are shown in Table (2) Mixed delicately by pipetting, close the tube centrifuged for a few seconds in a microcentrifuge (Micro-12, Korea-Hanil Science Industrial). At that point the reactions were incubated for 2-4 hours at the pointed out temperature for the enzyme (generally $37^{\circ} \mathrm{C}$ ). after high temperature inactivation the product of the reaction digest, $10 \mu \mathrm{l}$ of the digested samples were taken, included loading buffer, and were separated by electrophoreses on $2.5 \%$ agarose gel. One well (poket) every row was utilized for the length standard (100 bp DNA ladder) Bench top, volume $5 \mu$ l of length standard was utilized to gauge the size and concentration of the PCR product, the gel was visualized with Ethidum Bromide under the UV Transilluminator (Biostep-UST-20M-8K).

\section{Statistic Analysis}

The PROC GLM (General Linear Model) procedure SAS (2002) was used to analyze the data for the genotypes effects for weights at birth, one, two and three months (Weaning Weight) old and average daily gain from birth to weaning analyses were fitted to following equations:

$$
Y_{i j k l o}=\mu+A_{i}+S_{j}+C_{k}+P_{l}+\varepsilon_{i j k l o}
$$

Where: $\mathrm{Y}$ ijklo $=$ Body weight at different age and daily of $0^{\text {th }}$ lamb, of $\mathrm{i}^{\text {th }} \operatorname{MSTN}(\mathrm{Ai}, \mathrm{i}=1$, $\mathrm{BB})$, of $\mathrm{j}^{\text {th }}$ CAST $(\mathrm{Sj}, \mathrm{j}=1, \mathrm{AB}$ and $\mathrm{j}=2, \mathrm{BB})$, of $\mathrm{k}^{\text {th }}$ MHC-DBR1 ( $\mathrm{kk}, \mathrm{k}=1, \mathrm{AA}, \mathrm{k}=2, \mathrm{AB}$, $\mathrm{k}=3, \mathrm{AC}$ and $\mathrm{k}=4, \mathrm{CC})$, of $1^{\text {th }}$ all genes combinations ( $\mathrm{Pl}, \mathrm{l}=1,2,3,4,5$ and 6$), \quad, \mu=$ Population mean, $\boldsymbol{E}_{i j k l o}=$ random error. It was assumed to be normally and independently distributed with mean zero and variance $\delta^{2} e$.

\section{RESULTS AND DISCUSSION}

\section{Body weight of lambs at different ages}

The overall mean of male and female lamb's body weights at birth, one, two, weaning weight and average daily gain from birth to weaning were gives in Table (3).

Table (2): PCR product digestion components with their volume for all genes under study.

\begin{tabular}{|c|c|}
\hline Digestion Component & Volume \\
\hline Sterile, deionized water & $5.3 \mu \mathrm{l}$ \\
\hline Reaction $10 \mathrm{X}$ buffer & $2 \mu \mathrm{l}$ \\
\hline Acetylated BSA $10 \mu \mathrm{g} / \mu \mathrm{l}$ & $0.2 \mu \mathrm{l}$ \\
\hline DNA(PCR product) mix by pipetting & $7 \mu \mathrm{l}$ \\
\hline Appropriate Reaction Enzyme & $0.5 \mu \mathrm{l}(5 \mathrm{U})$ \\
\hline Final Volume & $15 \mu \mathrm{l}$ \\
\hline
\end{tabular}

\section{Molecular Profile}

Limited molecular genetic information using RFLP markers is available on Iraqi Awassi sheep. Most of the results obtained in this study were the first attempt as a molecular characterization of this breed in Iraq. Fig. (1) shows extracted genomic DNA of total (46) blood samples from Awassi lamb which indicate that the quality of DNA samples are very good and can be used for future work and genetic analysis.

\section{PCR- RFLP TECHNIQUE \\ PCR-RFLP FOR CAST GENES}

The PCR products for the CAST genes were digested with MspI restriction enzyme Nanekarani et al., (2011) followed by all samples run on $2.5 \%$ agarose gel electrophoresis to detect the genotype for each animal. The digested $(622 b p)$ fragment in calpastatin gene gave two genotypes. The BB genotype exhibited 2 fragments of 336 and $286 \mathrm{bp}$ and $\mathrm{AB}$ genotype exhibited 622,336 and 228 bp (Fig. 2). These results indicate that suitable diversity in Awassi sheep breed for calpastatin gene, that can used in future breeding programs. In the present study the diversity is perceived and consisting with 
reports on the other breeds (Gabor et al., 2009 and Shahram and Majid, 2014). Allelic and genotype frequency of CAST gene as given in Table

Table (3): Mean \pm SD of lamb's weight at different ages.

\begin{tabular}{ccccc}
\hline Lamb & No. & Birth weight $(\mathbf{K g})$ & Weaning weight $(\mathrm{Kg})$ & Average daily gain $(\mathrm{Kg})$ \\
\hline Male & 25 & $4.55 \pm 0.68$ & $21.38 \pm 3.80$ & $0.187 \pm 0.03$ \\
\hline Female & 21 & $4.25 \pm 0.69$ & $19.82 \pm 2.94$ & $0.172 \pm 0.03$ \\
\hline Overall & 46 & $4.4 \pm 0.685$ & $20.6 \pm 3.37$ & $0.179 \pm 0.03$ \\
\hline
\end{tabular}

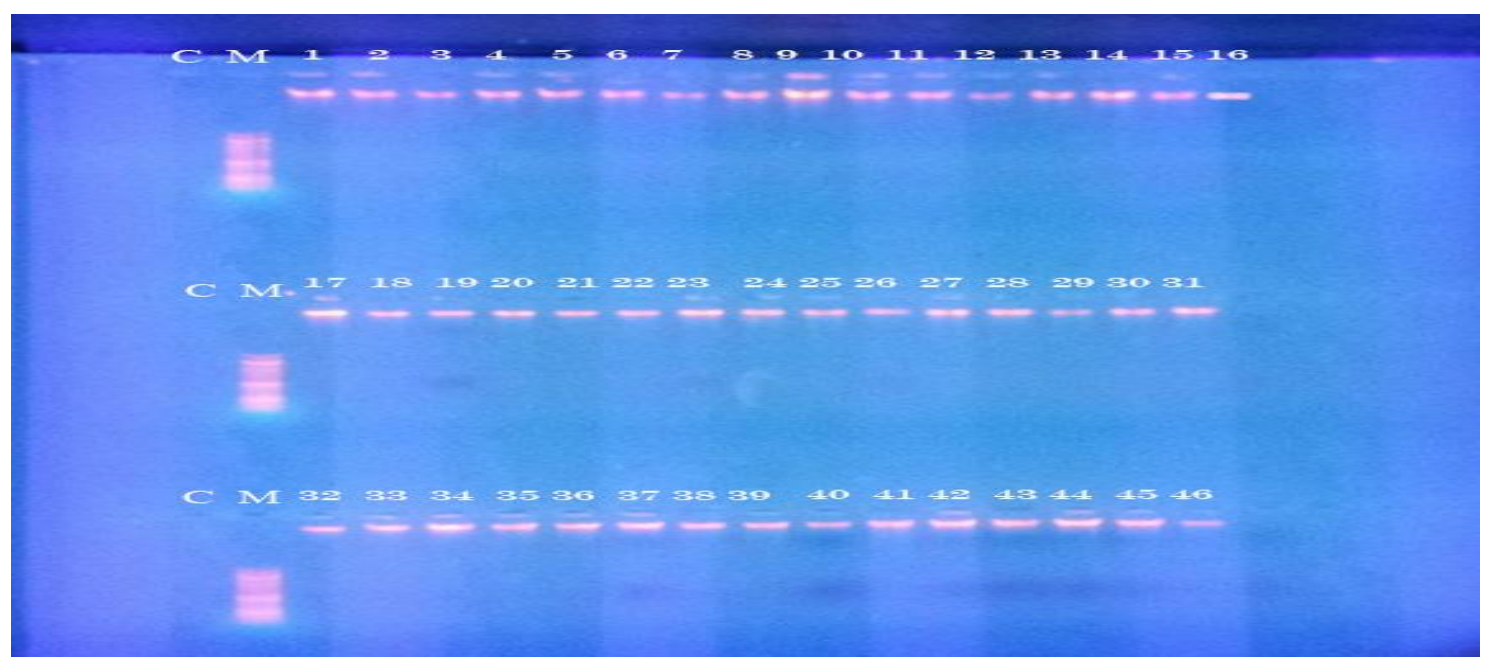

Fig. (1): DNA extraction image for 46 samples Awassi lambs C: Control without blood sample, M: DNA Ladder $100 \mathrm{bp}$

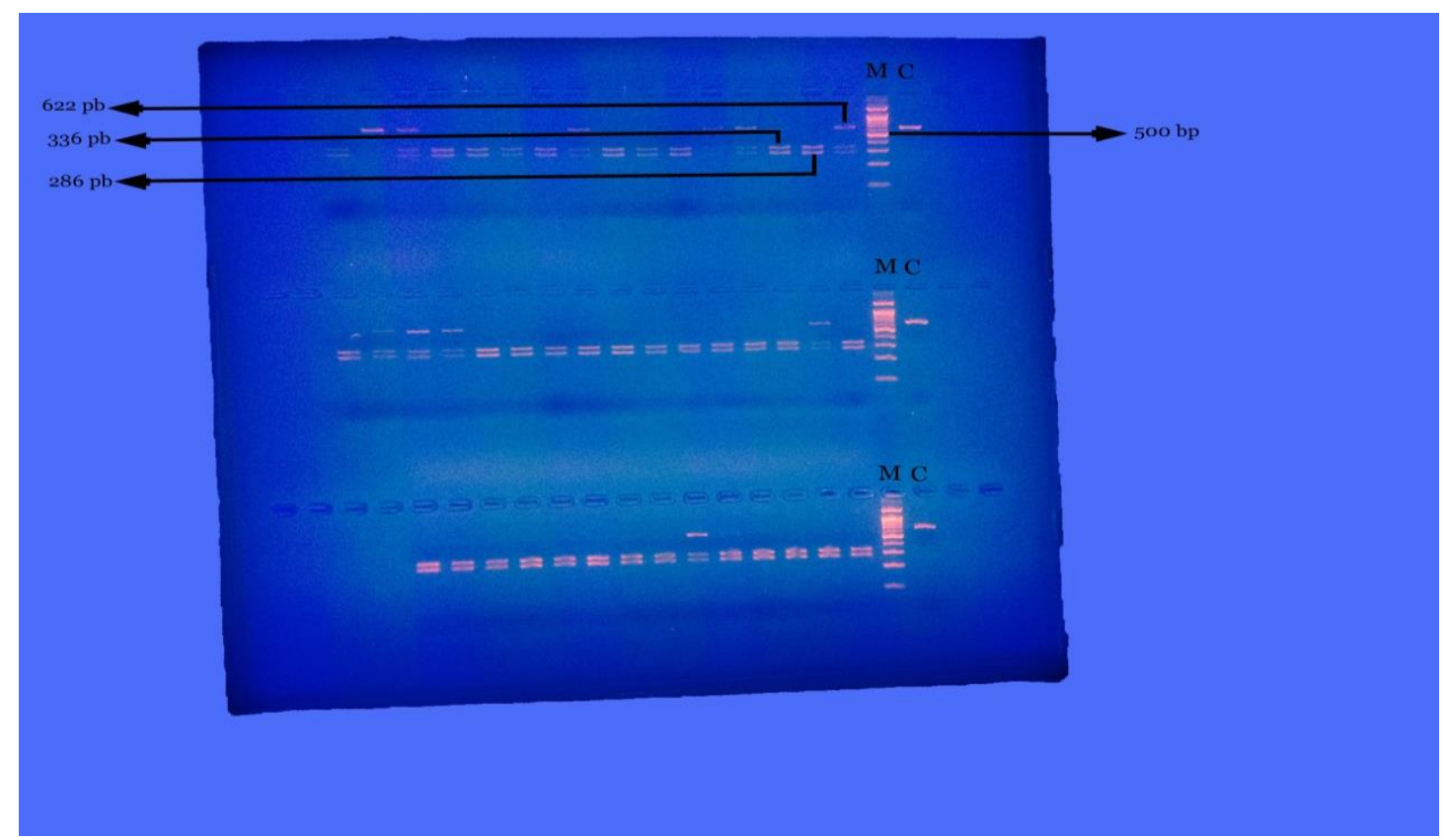

Fig. (2): PCR-RFLP analysis of $622 b p$ fragment of CAST gene by $M s p I$ enzyme on $2.5 \%$ agarose gel electrophoresis to separate bands with stained with $10 \mu 1$ Ethidium Bromide, $\mathrm{C}=$ Negative control and $\mathrm{M}=$ Molecular size. 
Table (4): Allelic and Genotype frequency of CAST gene in Awassi lambs

\begin{tabular}{lcccc}
\hline \multicolumn{1}{c}{ Genotypes } & \multicolumn{2}{c}{ Allelic frequency } & \multicolumn{2}{c}{ Genotype frequency } \\
\hline$B B(n=35)$ & $B$ & $A$ & $B B$ & $A B$ \\
\hline$A B(n=11)$ & 0.88 & 0.12 & 0.7609 & 0.2391 \\
\hline
\end{tabular}

\section{PCR-RFLP for MSTN Gene}

The DraI Restriction enzyme was used to digest the amplified PCR fragments (497 bp) according to Xianglong et al., (2008). After that the digested product for each sample was run on $2.5 \%$ agarose gel electrophoresis to detect the genotype for all samples. The results show only one genotype for all samples, the BB genotype (427and $70 b p$ ) was present in Fig. (3).

\section{PCR-RFLP for MHC-DRB1 Gene}

The PCR products for the MHC-DRB1 gene were digested with RsaI restriction enzyme (Ashrafi et al., 2014). Samples were migrated on a $2.5 \%$ agarose gel. Four genotypes were observed. Genotype (AB) with three fragments (279, 195 and $84 b p$ ), genotype (CC) with two fragments (200 and $79 \mathrm{bp}$ ). The genotype (AC) with three fragments $(279,200$ and $79 b p)$ and (AA) with one fragment (279 bp), (Fig. 4). Allelic and Genotype frequency of MHCDRB1 gene are demonstrated in Table (5).

Table (5): Allelic and Genotype frequency of MHC-DRB1 gene in Awassi lambs

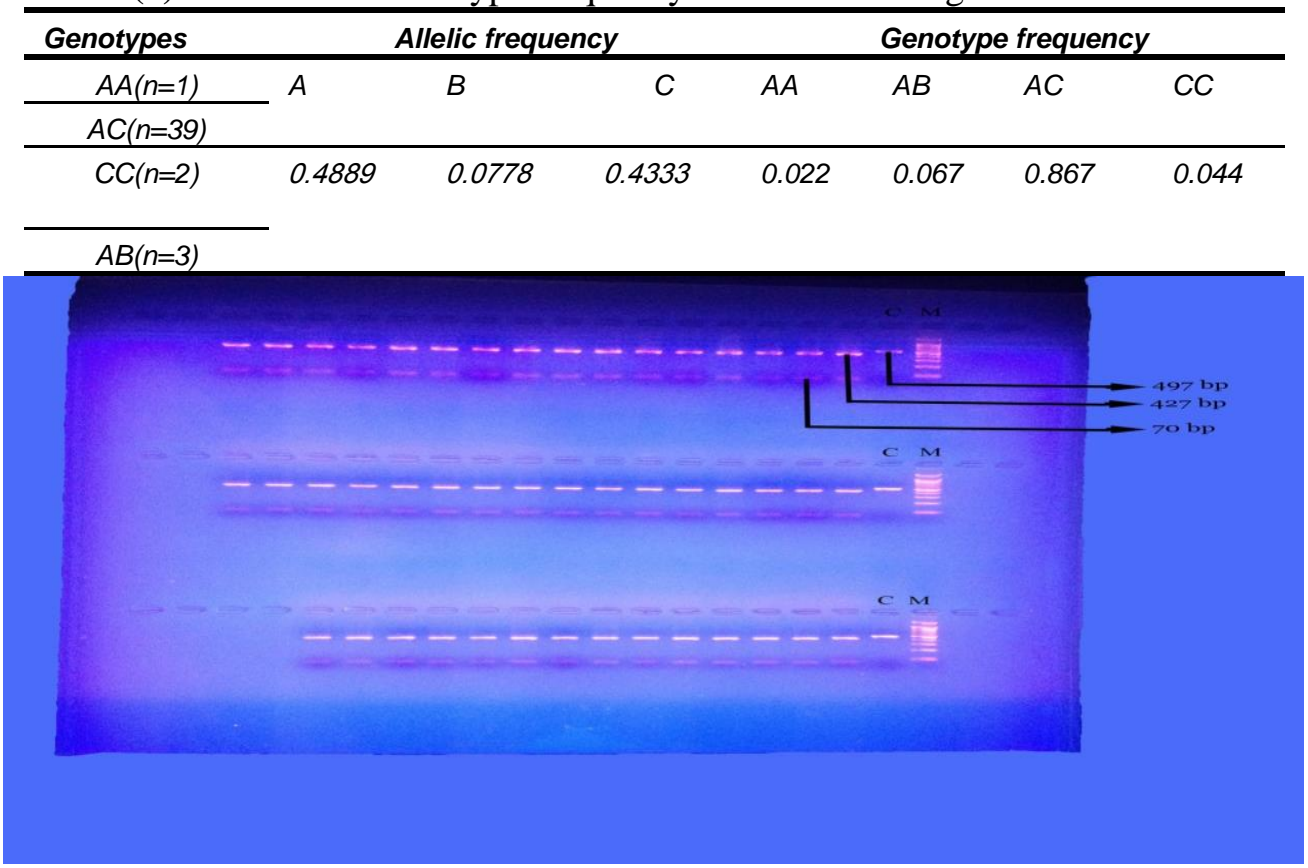

Fig. (3): The results of analysis PCR-RFLP for MSTN gene by restriction enzyme DraI on $2.5 \%$ agarose gel electrophoresis. Stained with $10 \mu 1$ Ethidium Bromide. $C=$ Negative control and $M=$ Molecular size. 


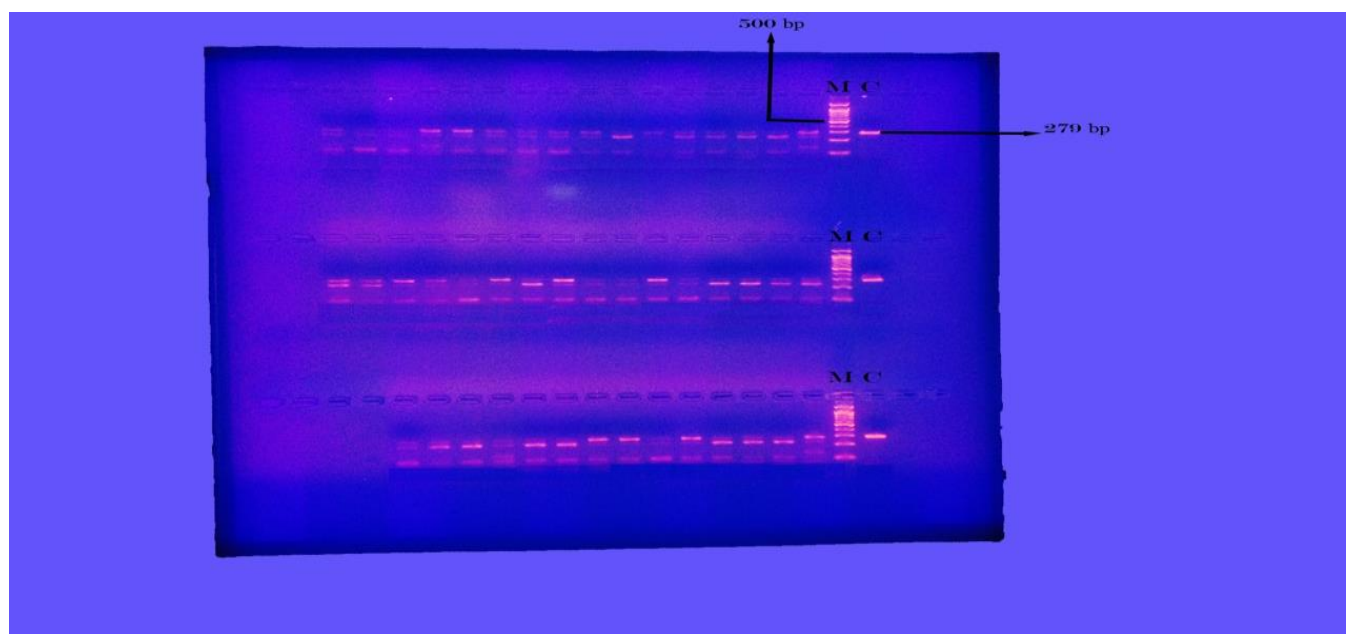

Fig. (4): PCR-RFLP analysis of $279 b p$ fragment of MHC-DRB1 gene by RsaI enzyme on 2.5\% agarose gel electrophoresis to separate bands with stained with $10 \mu 1$ Ethidium Bromide, $\mathrm{C}=$ Negative control and $\mathrm{M}=$ Molecular size marker (100 $b p$ DNA ladder).

\section{Molecular Markers and Quantitative Traits}

The effect of genetic markers on growth traits in Awassi lambs under investigation study are showed in Fig. (5). The $\mathrm{CC}$ genotypes of MHC-DRB1 had a positive effect on body weight at all ages except body weight at birth and on average daily gain. The $\mathrm{AB}$ genotype at CAST locus gave higher body weight at all ages and higher daily gain compared with BB genotype. Thus the best genotype for lambs at three loci in the present study was BBCCBB which gave $22.15 \mathrm{~kg} / \mathrm{lambs}$ with 0.197 $\mathrm{kg} / \mathrm{lamb} /$ day (Table 5). These results reveal that selection can play major role to increase body weight especially weaning weight in Awassi sheep.

This result is similar with Khan et al., (2012), who found in the CAST gene with MN genotype in Balkhi sheep give daily gain higher than the MM genotype at four months' age. Similar results were repoted by Gorlov et al., (2016) for the CAST gene in Salsk sheep and by Ashrafi et al., (2014) in Iranian Makuie sheep.

\section{CONCLUSIONS}

CAST and MHC-DRB1 genes were polymorphism while the MSTN gene was monomorphism. Lambs with $\mathrm{CC}$ genotype for MHC-DRB1 and lambs with $\mathrm{AB}$ genotype for CAST locus gave higher body weight at all ages and higher average daily gain. Lambs with BBCCBB genotypes gave about $1.5 \mathrm{~kg} / \mathrm{lamb}$ higher weight at weaning compared with all other genotypes. Thus, the investigation of three specific genes in Awassi lambs indicating the possibility of early selection of animals based on identifying specific genotype to improve the studied trait(s).

\section{ACKNOWLEDGEMENTS}

The authors are grateful to the Salahaddin University-Erbil to support this MS.C project study. 


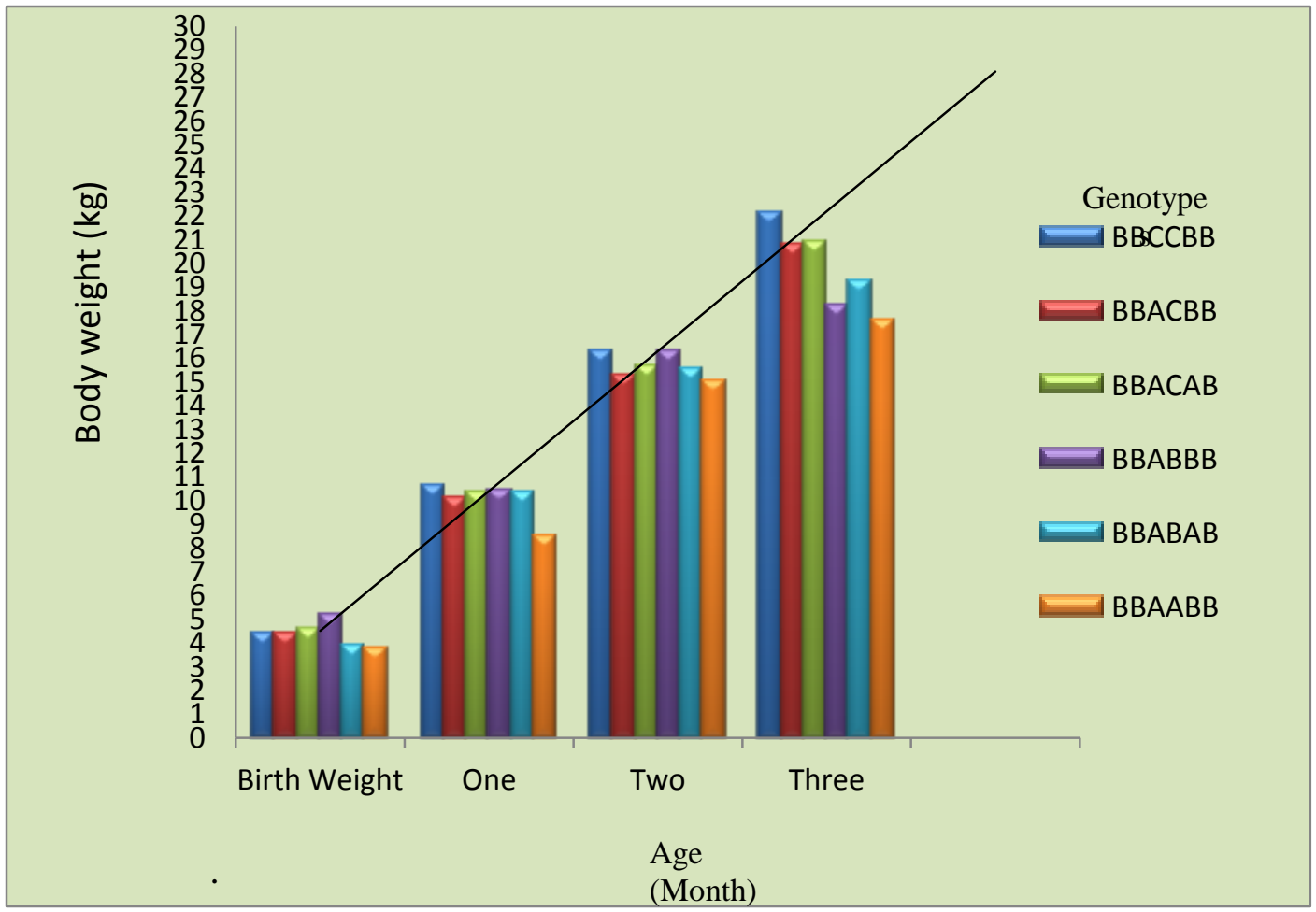

Fig. (5): Effect of loci genotype on the lambs body weight at different ages.

\section{REFERENCES}

Al-Azzawi, W. A. R., Al-Salman, M. H., and Hamad, S.A. (1995).Relationship between body weight and dimention traits in Awassi sheep. Proceeding the Regional Symposiom on integrated Croplivestock system in west Asia and North Africa 6-8 November, Amman, Jordan; 284-290.

AL-Barzinji, Y.M.S., and Gardi, H.E.A. (2012). Prediction of breeding value of awassi rams based on progeny performance in Kurdistan region of Iraq. Proceedings of the 15th AAAP Anim. Sci. Congress; 26-30.

AL-Barzinji, Y.M.S., and Gardi, H.E.A. (2015). Genetic evaluation and factors affecting post weaning growth performance and body dimensions of Awassi lambs. J. of Zankoi Sulaimani;17 (3) (Part-A). P. 25-31.

Al-Rawi, A. A, Al-Haboby A.H., and Salman A. (1996).Small ruminants breeding, reproduction physiology research as technology transfer in Iraq (W. Mourani, N. Haddad, Eds.), ICARDA West Asia Regional Program, Amman, Jordan.

Ammer, H., Schwaiger, F.W., Kammerbauer, C., Gomolka, M., Arriens, A., Lazary, S., and Epplenj, T.(1992). Exonic polymorphism vs. intronic simple repeat hypervariability in
MHC-DRB genes. Immunogenetics; 35:.332340 .

Ashrafi, F., Mardani, K., Ali, H.A., Darvishzadeh, R., and Farhadian, M. (2014). Association of molecular polymorphism in exon 2 of OvarDRB1 gene with weight traits in Iranian Makuie sheep breed. Turk J Vet Anim., Sci. ; 38:126-132.

Baumung, R., Simianer, H.H., and Hoffmann, I. (2004). Genetic diversity studies in farm animals - a survey. J Anim Breed Genet; 121. P. 361-373.

Chu, M. X., Liu, Z.H., Jiao, C.L., He, Y.Q., Fang, L., Ye, S.C., Chen, G.H., and Wang, J,Y.(2007). Mutation in BMPRIB and BMP15 genes are association with litter size in Small Tailed Han sheep (Ovis aries). J Anim Sci; 85:.598-603.

Davis. G.H., Galloway, S.M., Ross, I.K., Gregen, S.M., Ward, J., Nimbkar, B.V., Ghalsasi, P.M., Nimbkar, C., et al. (2000). DNA tests in prolific sheep from eight countries provide new evidence on origin of the Booroola (FecB) mutation. Biol Reprod ; 66:1869 1874.

FAO, (Food and Agriculture Organization), (2000). Quarterly bulletin of statistics 1. FAO. Rome, Italy.

\footnotetext{
*E-Mail: Yousif.Noori@Su.Edu.Krd, Y_Barzengy@Yahoo.com
} 
Gabor, M.A., Trakovicha, A., and Miluchova, M. (2009). Analysis of polymorphism of CAST gene and Clpg gene in sheep by PCR-RFLP method. J. Zoot. Biotehnol; 42: 470-476.

Gorlov, I., Shirokova, V., Randelin, A., Voronkova, V., Mosolova, N., Zlobina, E., etal. (2016). CAST/MspI gene polymorphism and its impact on growth traits of Soviet Merino and Salsk sheep breeds in the South European part of Russia. Turk J Vet Anim Sci.; 40:399405.

Hanrahan, J. P., Gregen, S. M., Mulsant, P., Mullen, M., Davis G. H., Powell R. and Galloways, S.(2004). Mutations in the genes for oocyte derived growth factors GDF9 and BMP15 are associated sheep (Ovis aries). Biol. Reprod. 70. P.900-909.

Khan, S., Riaz, M., Ghaffar, A., and Khan, M. (2012). Calpastatin (CASTA) gene polymorphism and its association with average daily weight gain in Balkhi and Kajli sheep and Beetal Goat breeds. Pakistan J Zool ; 44(2): 377-382.

Moradband, F., Rahimi, G., and Gholizadeh, M.(2011). Association of polymorphisms in Fecundity Genes of GDF9, BMP15 and BMP15-1B with Litter Size in Iranian Baluchi Sheep. Asian-Aust J Anim Sci ; 24 (9): 1179-1183.
Nanekarani, S., Asadi, N., Khederzadeh, S.(2001). Genotypic frequency of calpastatin gene in lori sheep by PCR-RFLP method . 2nd International Conference on Environmental Science and Development IPCBEE vol.4, IACSIT Press, Singapore.

SAS, Statistical Analyses System.(2002). SAS/STAT User's Guide, Version 8, first edition, Cary, NC, USA.

Shahram, N. and Majid, G. (2014). Polymorphism of candidate genes for meat production in Lori sheep. IERI Procedia; 8: 18 - 23.

Shahroudi, F. E., Nassiry, M. R., Valizadh, R., Moussavi, A.H., Tahmoorespour, M., and Ghiasi, H. (2006). Genetic polymorphism at MTNR1A, CAST and CAPN loci in Iranian Karakul sheep. Iranian J Biotechnology; 4(2): 117-122.

Williams, J.L. (2005). The use of marker-assisted selection in animal breeding and biotechnology. Scientific and Technical Review, Office International Des Epizooties ; 24:379-391.

Xianglong, L., Zhengzhu, I., Rongyan, L., Guiru, Z., Yuanfang, Z. G., and Lanhui, L. I. (2008). Deletion of TTTTA in 5 UTR of goat MSTN gene and its distribution and genetic effect on body weight. Front. Agric. China; 2(1): 103109. 
كارليّكردنى بوَهيّلَه تايبهته كان لهسهر كيّشى مهرى عهواسى عيّراقى

يوخته

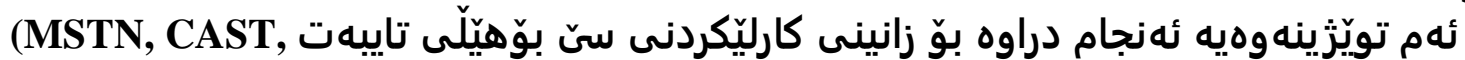

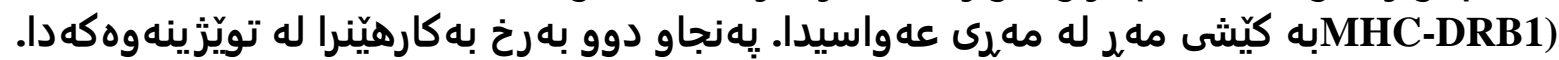

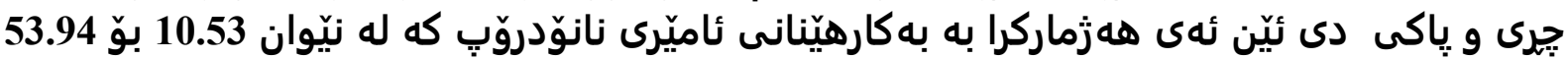

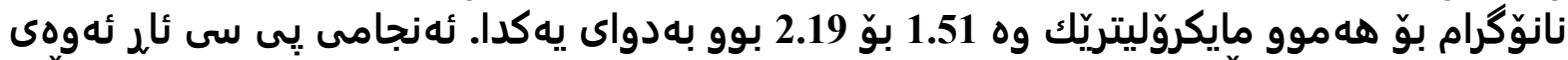

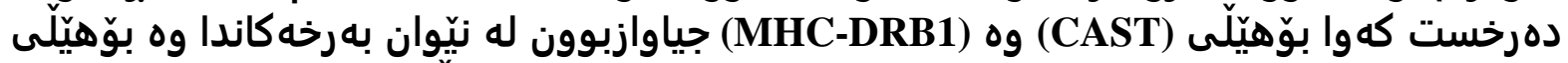

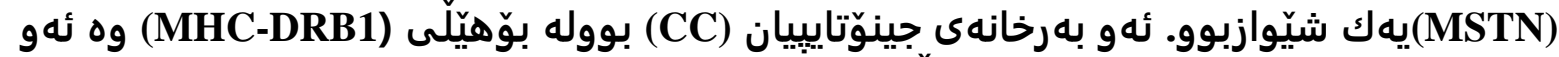

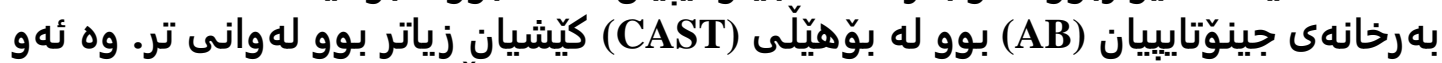

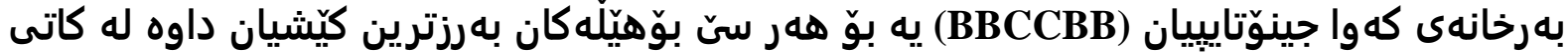

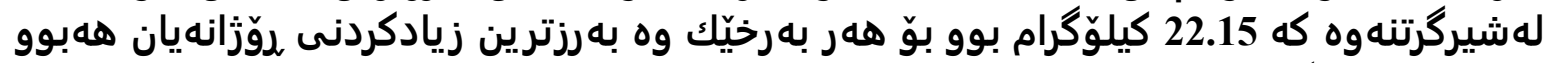

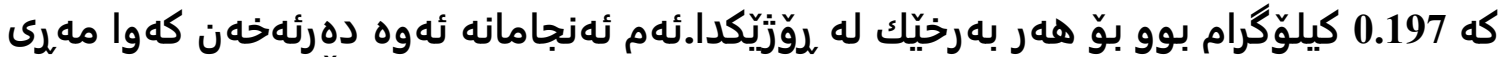

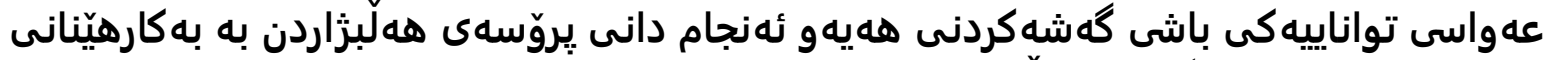

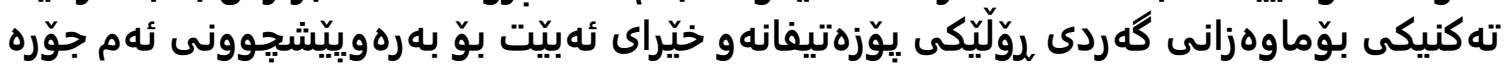
مهره له عيّراقدا.

\section{تاثير الجينات الخاصة على وزن الجسم في الأغنام العواسية العراقية}

الخلاصة

أجريت هذه الدراسة لمعرفة تأثير ثلاث جينات خاصة بالأوزان (MSTN, CAST, MHC-DRB1)

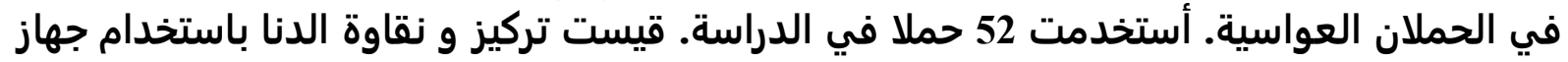

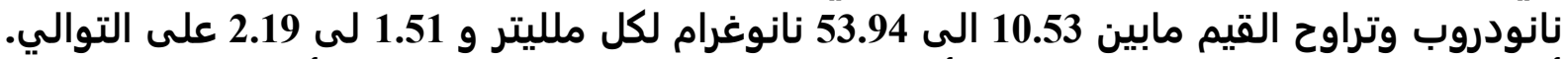

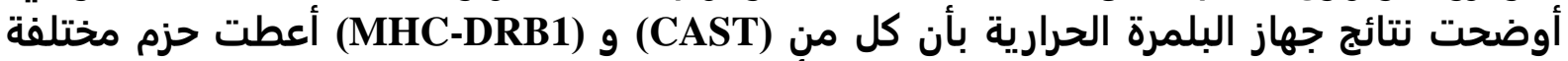

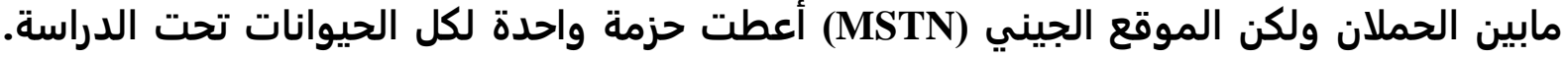

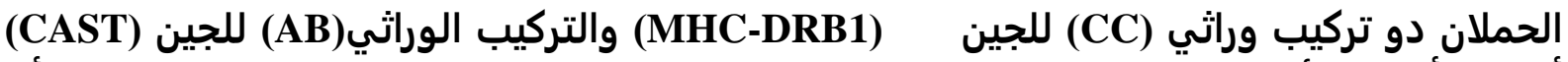

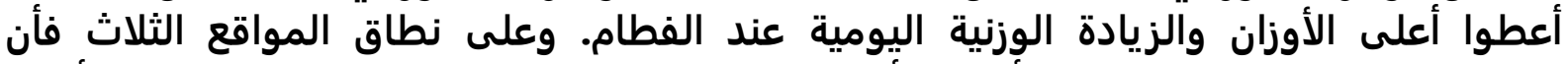

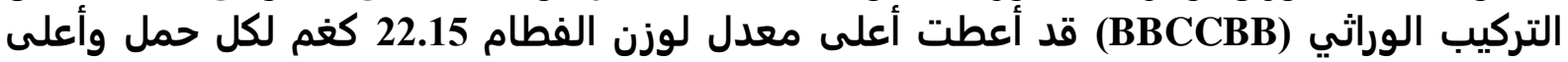

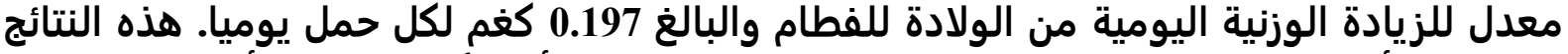

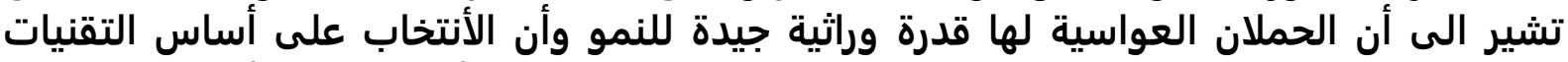
الوراثية الجزيئية لها دور فعال في تسريع عمليات التحسين للأوزان في الأغنام العواسية العاسية العراقية. 